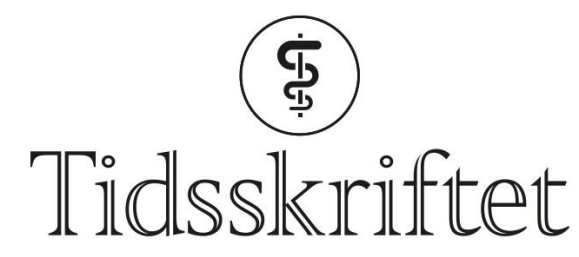

DEN NORSKE LEGEFORENING

\title{
Knud Holck Landmark
}

MINNEORD

FINN OLAV LEVY

JAN-BJØRN OSNES

TOR SKOMEDAL

ÅSMUND REIKVAM

HELGE REFSUM

INGRID OS

ARNE WESTHEIM

Professor emeritus Knud Holck Landmark døde 28. september 2019. Den menneskekjære og livsglade allmennpraktikeren, hjertespesialisten, forskeren og farmakologen er gått bort, 88 år gammel.

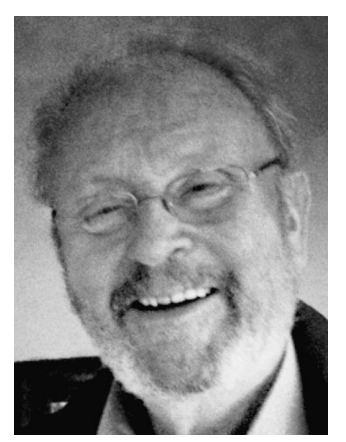

Etter ferdig legeutdannelse i Oslo i 1956, turnus i Gjøvik og Nord-Fron, militærtjeneste i marinen, allmennpraksis på Raufoss og indremedisin på Krohgstøtten sykehus vendte han blikket mot forskning. Som allmennpraktiker hadde han blitt oppmerksom på at enkelte pasienter som ble behandlet med psykofarmaka, fikk hjerterytmeforstyrrelser. Dette ble utgangpunktet for hans forskningsfelt. I doktorgraden The Mode of Action of Promazine and Thioridazine in Isolated Rat Cardiac Muscle, utført ved Fysiologisk institutt og Farmakologisk institutt ved Universitetet i Oslo, studerte han effektene av psykofarmaka på hjerterytmen $\mathrm{i}$ eksperimentelle modeller. Dette la grunnlaget for senere studier og bidro til at nye medikamenter i dag utvikles uten slike bivirkninger. 
Senere ble han spesialist $\mathrm{i}$ indremedisin og i hjertesykdommer og arbeidet ved Hjertemedisinsk avdeling, Rikshospitalet, Medisinsk avdeling, Lovisenberg sykehus og Hjertemedisinsk avdeling, Ullevål sykehus, før han i 1993 ble professor ved Institutt for farmakoterapi. Her var uavhengig informasjon om legemidlers virkninger og bivirkninger den sentrale oppgaven, bl.a. gjennom en rekke artikler om blodtrykksbehandling. Han var idérik og hadde forslag til flere nye forskningsprosjekter. Hele tiden opprettholdt han en betydelig vitenskapelig produksjon, som spente fra eksperimentelle studier av medikamentvirkning, bl.a. om kalsiumkanalblokkere og andre antiarytmika, til kliniske studier og en rekke oversiktsartikler om medikamentell behandling, særlig rettet mot kardiovaskulære sykdommer og spesielt blodtrykksbehandling.

I perioder var han leder for legemiddelkomiteer, hovedtillitsvalgt for leger ved Universitetet i Oslo og sensor ved medisinsk embetseksamen. Til han selv var 80 år var han tilsynslege ved Eikstunet bo- og behandlingssenter i Bærum. Også lenge etter at han ble pensjonist, fortsatte han å skrive faglige artikler om aktuelle temaer innen medikamentell behandling. Først 84 år gammel ryddet han kontoret på Farmakologisk institutt og takket for seg.

Knud var omgjengelig, vennlig og omtenksom - en gentleman. Han satte stor pris på sine fem barn og mange barnebarn og oldebarn og ønsket å kunne følge dem lenger.

Vi lyser fred over hans minne og takker for alle faglige bidrag og gode minner. Våre tanker går til hans kone Trine og resten av familien.

Publisert: 9. desember 2019. Tidsskr Nor Legeforen. DOI: 10.4045/tidsskr.19.0735

(C) Tidsskrift for Den norske legeforening 2020. Lastet ned fra tidsskriftet.no 